\title{
The Basic Philosophy of Organizing Study Program Outside the Domicile of Universities in Indonesia That Is Fair
}

\author{
Muhammad Lutfi Syarifuddin; I Nyoman Nurjaya; Slamet Suhartono \\ Faculty of Law, Universitas 17 Agustus 1945 Surabaya, Indonesia \\ http://dx.doi.org/10.18415/ijmmu.v8i9.3016
}

\begin{abstract}
The type of research in this legal research is normative legal research. With the aim of equalizing education and fulfilling the special rights of every citizen in terms of education, educational programs outside the domicile are coordinated as regulated in Permendiknas No.20-2011. Until now, the implementation of study program learning outside the domicile is still dominated by State Universities, considering that only State Universities can fulfill the need to organize study program education outside the domicile.
\end{abstract}

Keywords: Domicile; Universities; Fair

\section{Introduction}

Education has a very basic role in everyday life, both in the individual sphere and at a broader level, so that it becomes one of the basic pillars that helps the survival of a country.(Mardiah \& Syarifudin, 2019)

This concept is the reason for directing the implementation of instructions in the constitution of each country, considering that for Indonesia, which clearly regulates education in the 1945 Constitution of the Republic of Indonesia (UUD NRI 1945).(Sukendar et al., 2021) Each type of teaching (formal, nonformal, and informal) as well as every level of education (elementary, secondary and higher) is a type of form of National education that complements and cooperates with one another, as stipulated in the Law of the Republic of Indonesia Number 20 of the Year 2003 on the National Education System (Law No. 202003), Article 24. It's proposed to provide freedom at the most extreme turn of events and investigations at the tertiary level to create individuals who have a bachelor's degree, but also have the necessary information and abilities capable as funding to provide benefits to the community.

Given the academic and institutional self-governance of a college, it has the privilege of developing a variety of techniques for delivering education that are expected to help achieve the goals of public teaching. This includes the implementation of study programs outside the domicile of the university, which is mandated in the Regulation of the Minister of National Education of the Republic of Indonesia Number 30 of 2009 concerning the Implementation of Study Programs Outside the Domicile of the College, which was later replaced by the Regulation of the Minister of National Education of the Republic of Indonesia Number 20 of 2011 concerning Implementation of Study Programs Outside the Domicile of Higher Education. (Permendiknas No. 20-2011) 


\section{Research Methods}

The type of research in this legal research is normative legal research. (Karina Sari Wijayanto Putri, Slamet Suhartono, 2021)

\section{Discussion}

One of the public authorities' efforts to overcome this problem is through the service of the national ministry of education which provides various laws that give state universities the freedom to regulate their study programs outside their domicile. Because the limit of the study program at the domicile is not enough. Thus, public authorities feel responsible for making State Universities provide and require higher level education to the Indonesian people.

Given the picture identified with the problems referred to above, public authorities through the Ministry of National Education provide an approach to implementing study programs outside the domicile of higher education institutions, for this situation, especially State Universities, as well as Private Universities. Colleges that meet the prerequisites listed in the Guidelines. Arrangements for the implementation of teaching (study programs) outside the domicile depend on Permendiknas No. 20-2011.

One of the main requirements that must be owned is that a state university or private university that organizes educational programs outside the domicile has obtained or taken accreditation with list A for similar reporting programs domiciled in that education; Then, at that time what was no less important was the place where the study program was carried out outside the domicile had been supported by the local government of the Regency/City that would be occupied.

Whereas what is meant by the domicile of the tertiary institution is the place in the Regency/City area that will be used as a place for the establishment of the tertiary institution as stated in the permit for the establishment of the Regency/City which is directly adjacent to the Regency/City where the tertiary institution is located, in accordance with what has been stated in Article 1 paragraph (1) and Article 3 paragraph (1) Permendiknas No. 20-2011.

Not only that, even the development of study programs outside the domicile is carried out with the rules of public responsibility for higher education with a quality comparable to similar reporting programs at the residence of the college to be followed.(Harris, 2017)

In the Law of the Republic of Indonesia Number 12 of 2012 concerning Higher Education (Law No. 12-2012), there is education conducted outside the campus. However, regardless of whether "off campus" can be compared with "out of domicile", this requirement requires further clarification.(Laksono, 2019)

Somewhere outside the instructional framework, the requirement of socialization among students to have the option of meeting face-to-face cannot be fully implemented without problems.(Lutfiana \& Rizki, 2020) Theoretically, the implementation of remote classroom instruction provides benefits or advantages for students' local areas. Because getting a distant class will save you a lot of costs.

In 1997 in Circular No. 2559/D/T/97 explicitly the term distance class is a learning model that is completed remotely without permission. Public authorities only give approval for remote instruction coordinated by the Open College. Furthermore, it was reaffirmed in Circular No. 2630/D/T/2000, that the implementation of remote class programs other than the Open Higher Education model is prohibited. Meanwhile, State Universities and Private Universities are left to sort out the realization of the Open Higher Education model which will be controlled in different guidelines. The term "prohibition class" continues to be creative in different forms. 
In the case of remote classes lectures can run safely and don't experience major obstacles, among others, carried out differently, one of which is by cooperating with security organizations, or environmental universities. There are about four reactions that arise; first, communicate their protest because they feel they aren't holding remote classes; second, communicating complaints despite the fact of holding distant classes; third, try to avoid panic and keep holding classes far away; fourth, admitting holding distant classes and asking respectable people to take action gradually.

The existence of the principle of justice that underlies the implementation of education outside the domicile in Indonesia in accordance with Law No. 20-2003 which states that "Implementing teaching must be fair and reasonable and unbiased while maintaining basic freedom, strict quality, social quality, and reliable public pluralism". (Widjiastuti et al., 2020)

The standard of equity in the administration of education is also in accordance with Law No. 202003 Article 4 paragraph (1) which reads "Education is carried out fairly and properly and isn't oppressive by maintaining basic freedoms, strict quality, social quality, and the diversity of nations." Jeremy Bentham says happiness is pleasure and the absence of pain. (Guidi, 2009)

\section{Conclusion}

With the aim of equalizing education and fulfilling the special rights of every citizen in terms of education, educational programs outside the domicile are coordinated as regulated in Permendiknas No.202011. Until now, the implementation of study program learning outside the domicile is still dominated by State Universities, considering that only State Universities can fulfill the need to organize study program education outside the domicile.

The implementation of education must be in accordance with the implementation standards according to Law No. 20-2003 Article 4. As a university that has the right to regulate itself in providing education outside of its domicile, it has the principle of responsibility in its implementation. Collectively, in order for the implementation of education outside the domicile to be successful, it must be completed in accordance with the overall standards for implementing national education in accordance with Article 4 of Law No. 20-2003 and Article 2 of the Regulation of the Minister of National Education of the Republic of Indonesia Number 30 of 2009 concerning the Implementation of Study Programs Outside the Domicile of Higher Education, in the implementation of education outside the domicile must also adhere to the principle of justice as a form of fulfillment of human rights. The principle of educational justice is also regulated in Law No. 20-2003 Chapter III Article 4 paragraph (1) and Article 5 paragraph (1) to paragraph (5). Education outside the domicile must meet the relevant regulations and prerequisites as stated in the current Laws and Ministerial Regulations.

\section{References}

Guidi, M. E. L. (2009). Jeremy Bentham. In Handbook of Economics and Ethics. https://doi.org/10.5840/tpm20042686.

Harris, F. (2017). ANALISIS SINGKAT PERUBAHAN STATUS HUKUM PERGURUAN TINGGI NEGERI MENJADI BADAN HUKUM MILIK NEGARA (BHMN). Jurnal Hukum \& Pembangunan, 34(3). https://doi.org/10.21143/jhp.vol34.no3.1437.

Karina Sari Wijayanto Putri, Slamet Suhartono, T. M. (2021). PENERAPAN SANKSI PIDANA KEPADA PELANGGAR PROTOKOL KESEHATAN DI TENGAN PANDEMI COVID-19. Jurnal Akrab Juara, 6(2), 214-231.. 
Laksono, L. B. (2019). Pendidikan Kewarganegaraan Mengusung Pancasila sebagai Konsensus Sosial, Kontrak Sosial, dan Social Imaginary. Integralistik, 30(2), 150-161. https://doi.org/10.15294/integralistik.v30i2.20876.

Lutfiana, R. F., \& Rizki, A. I. (2020). Urgensi Materi Bela Negara dalam Kegiatan Pengenalan Kehidupan Kampus bagi Mahasiswa Baru di Perguruan Tinggi. Jurnal Ilmu Pendidikan PKn Dan Sosial Budaya, $4(2)$.

Mardiah, M., \& Syarifudin, S. (2019). MODEL-MODEL EVALUASI PENDIDIKAN. MITRA ASHSHIBYAN: Jurnal Pendidikan Dan Konseling, 2(1). https://doi.org/10.46963/mash.v2i1.24.

Sukendar, A. Y. S., Raissa, A., \& Michael, T. (2021). Pelatihan Pembuatan Artikel Jurnal Nasional Terakreditasi dan Internasional Bereputasi Sebagai Implementasi Undang-Undang Republik Indonesia Nomor 20 Tahun 2003 Di Universitas 17 Agustus 1945 Surabaya. Fajar: Media Komunikasi Dan Informasi Pengabdian Kepada Masyarakat, 20(1). https://doi.org/10.15408/jf.v20i1.20324.

Widjiastuti, A., Warka, M., Suhartono, S., \& Hufron, H. (2020). Legal Protection of Patients Participants of Health Social Guarantee in Human Rights Perspective. International Journal of Multicultural and Multireligious Understanding, 7(10). https://doi.org/10.18415/ijmmu.v7i10.2135.

\section{Copyrights}

Copyright for this article is retained by the author(s), with first publication rights granted to the journal.

This is an open-access article distributed under the terms and conditions of the Creative Commons Attribution license (http://creativecommons.org/licenses/by/4.0/). 